\title{
Evaluation of Serum S100B Levels in Male Children Younger than 6 Years Old with Autism Spectrum Disorder: A Psychiatric and Biochemical Perspective
}

\author{
Otizm Spektrum Bozukluğu Olan 6 Yaşından Küçük Erkekler Çocuklarda Serum S100B \\ Düzeylerinin Değerlendirilmesi: Psikiyatrik ve Biyokimyasal Perspektif
}

\author{
Ayşe Nihal ERASLAN ${ }^{1}$ \\ (1) 0000-0002-7655-7927 \\ İbrahim DURUKAN ${ }^{2}$ \\ (D) 0000-0002-1844-6911 \\ Sahin BODUR ${ }^{2}$ \\ (D) 0000-0002-4942-7932 \\ Özge DEMİRCAN TULACI ${ }^{3}$ \\ (1) 0000-0002-7174-2154
}

\begin{abstract}
${ }^{1}$ Department of Child and Adolescent Psychiatry, Ankara Training and Research Hospital, Ankara, Turkey

${ }^{2}$ Department of Child and Adolescent Psychiatry, Gülhane Training and Research Hospital, Ankara, Turkey

${ }^{3}$ Department of Child and Adolescent Psychiatry, Balıkesir Atatürk City Hospital, Balıkesir, Turkey
\end{abstract}

\section{Corresponding Author Sorumlu Yazar \\ Ayşe Nihal ERASLAN \\ aysenihaleraslan@gmail.com}

Received / Geliş Tarihi : 02.08.2021 Accepted / Kabul Tarihi : 05.11.2021 Available Online /

Çevrimiçi Yayın Tarihi : 25.11.2021

\begin{abstract}
Aim: Autism spectrum disorder is a neurodevelopmental disorder. The S100 calcium binding protein B (S100B) is among the markers of astrocyte activation as well as brain damage. Herein, it was aimed to evaluate $\mathrm{S} 100 \mathrm{~B}$ levels to determine whether there is a relation with the severity of autism spectrum disorder and establish possible causes of different results among the studies in the literature from a psychiatric and biochemical perspective.

Material and Methods: Twenty-five male children with autism spectrum disorder were included as the study group along with twenty-seven male children as the control group. The childhood autism rating scale and the autism behavior checklist were applied. Serum S100B protein levels were measured by enzyme-linked immunosorbent assay (ELISA).

Results: The mean serum S100B level was $1008.61 \pm 171.34 \mathrm{pg} / \mathrm{mL}$ in the study group and $1060.14 \pm 182.83 \mathrm{pg} / \mathrm{mL}$ in the control group, and no statistically significant difference was found between the groups $(\mathrm{p}=0.300)$. Based on the childhood autism rating scale scores, $60 \%(n=15)$ of the children with autism spectrum disorder had severe autism, whereas $40 \%(n=10)$ had mild-to-moderate autism. There was no significant difference in terms of the serum S100B levels between the groups of autism spectrum disorder severity $(\mathrm{p}=0.935)$ or according to the autistic regression status $(\mathrm{p}=0.667)$.

Conclusion: For S100B to be accepted as a reliable biomarker for autism spectrum disorder, more studies considering some factors with larger samples should be performed. Moreover, to understand the effect of biochemical methodology on the results, further studies are suggested on this subject.

Keywords: Autism spectrum disorder; autism; S100B; neuroglial cells.
\end{abstract}

ÖZ

Amaç: Otizm spektrum bozukluğu nörogelişimsel bir bozukluktur. S100 kalsiyum bağlayıcı protein B (S100B), beyin hasarının yanı sıra astrosit aktivasyonunun da belirteçleri arasındadır. Bu çalışmada, otizm spektrum bozukluğunun şiddeti ile ilişkisi olup olmadığını belirlemek için S100B düzeylerinin değerlendirilmesi ve literatürdeki çalışmalar arasında farklı sonuçların olası nedenlerinin psikiyatrik ve biyokimyasal açıdan değerlendirilmesi amaçlanmıștır.

Gereç ve Yöntemler: Çalışma grubu olarak yirmi beş otizm spektrum bozukluğu olan erkek çocuk ve kontrol grubu olarak ise yirmi yedi erkek çocuk çalışmaya dahil edildi. Çocukluk otizm derecelendirme ölçeği ve otizm davranış kontrol listesi uygulandı. Serum S100B protein seviyeleri, enzyme-linked immunosorbent assay (ELISA) ile ölçüldü.

Bulgular: Ortalama S100B serum düzeyleri çalıșma grubunda $1008,61 \pm 171,34 \mathrm{pg} / \mathrm{mL}$ ve kontrol grubunda $1060,14 \pm 182,83 \mathrm{pg} / \mathrm{mL}$ idi ve gruplar arasında istatistiksel olarak anlamlı bir fark yoktu $(\mathrm{p}=0,300)$. Çocukluk otizm derecelendirme ölçeği puanlarına göre, otizm spektrum bozukluğu tanılı çocukların \%60'ı (n=15) şiddetli otizme sahipken, \%40’1 (n=10) hafif-orta otizme sahipti. S100B serum seviyeleri bakımından, otizm spektrum bozukluğu şiddet grupları arasında $(p=0,935)$ veya otistik regresyon durumuna göre $(p=0,667)$ anlamlı bir fark yoktu. Sonuç: S100B'nin otizm spektrum bozukluğu için güvenilir bir biyobelirteç olarak kabul edilebilmesi için daha geniş örneklem olan ve bazı faktörleri de dikkate alan daha fazla çalışma yapılmalıdır. Ayrıca biyokimyasal metodolojinin sonuçlara etkisini anlamak için bu konuda daha fazla çalışma yapılması da önerilmektedir.

Anahtar kelimeler: Otizm spektrum bozukluğu; otizm; S100B; nöroglial hücreler. 


\section{INTRODUCTION}

Autism spectrum disorder (ASD) is a neurodevelopmental disorder characterized by marked delays and deviation in the area of social communication and social interaction and restricted and repetitive patterns of behavior, interests, or activities starting in early childhood (1). ASD is known as a multifactorial disorder comprising the interactions of neurological, immunological, environmental, and genetic factors (2). Identifying a biomarker for ASD has been stated to be important as it will be of diagnostic and prognostic value, reflecting the underlying situation or disease (2).

S100 calcium binding protein B (S100B) is most abundant in the glial cells of the central nervous system (CNS), predominantly in astrocytes, indicating astrocyte activation. The intracellular role of S100B includes participation in cell proliferation, differentiation, transcription, survival, and enzyme activities, whereas its extracellular role is exerted mostly through receptors for advanced glycation end-products (RAGE) and triggering intracellular signaling cascade, leading to processes such as neuroinflammation and neurodegeneration (3-5). It has been confirmed that the action of S100B is either neurotrophic/neuroprotective or neurotoxic/apoptotic depending on the concentration $(3,6)$. In neural cultures neurotrophic effects have been demonstrated at nanomolar levels and apoptotic effects at micromolar levels (5). In the study by Kleindienst et al. (3) it was found that the astrocytic neurotrophic protein S100B is a potential candidate to increase progenitor cell proliferation following traumatic brain injury and it appears to enhance hippocampal network repair and improve cognitive recovery. Increased levels of S100B may be prior to a significant change in neurological function or neuronal cell death (7).

S100B may contribute to developmental pathogenesis in psychiatric diseases (2). Alterations in S100B levels in patients with schizophrenia and mood disorders have been reported (4). Studies investigating the relation between S100B values and ASD in children revealed intriguing results. Elevated serum S100B levels in children with ASD have been reported by Al-Ayadhi and Mostafa (7), Ayaydın et al. (8), and Golubova et al. (9), whereas elevated plasma S100B levels in children with ASD have been shown by Guloksuz et al. (10) and Tomova et al. (5). On the other hand, Esnafoglu et al. (2) reported that there was no difference in serum S100B between children with ASD and a healthy control group.

In the present study we aimed to determine whether serum S100B concentrations in ASD patients are elevated and differ in terms of clinical severity in a more homogeneous study group in terms of age range and sex. For this purpose, serum levels of S100B were measured in order to contribute to the elucidation of the etiopathogenesis of ASD. After the analysis in addition to the mentioned aim, the possible causes of different results among studies were examined from both a psychiatric and a biochemical perspective.

\section{MATERIAL AND METHODS Study Design}

This was a two-centered cross-sectional and descriptive study that was performed at Gülhane Medical School
Child and Adolescent Psychiatry Department, Dr. Sami Ulus Gynecology Obstetrics and Child Health and Diseases Training and Research Hospital Child and Adolescent Psychiatry Department, and Dr. Sami Ulus Gynecology Obstetrics and Child Health and Diseases Training and Research Hospital Pediatric Department between January 2015 and June 2015.

It was determined to include 23 individuals as appropriate for both the control and the study group when taking the $\alpha=0.05, \beta=0.20$, the standard deviation as 43 , and the difference of mean values of S100B between groups as 36 based on the study by Al-Ayadhi and Mostafa (7).

Twenty-five male with ASD were included as the study group and 27 male as the control group. All male were under 6 years old. ASD was diagnosed by two different child and adolescent psychiatrists according to DSM-5 (Diagnostic and Statistical Manual of Mental Disorders-5) criteria. The controls were recruited from among children that were presented to the general pediatrics outpatient clinic for minor physical problems.

Having a diagnosed neurological illness (such as epilepsy), chronic systemic disease (such as chronic renal failure, chronic heart disease, or autoimmune disorders), or comorbid psychiatric disorder (except intellectual disability for the ASD study group) and using any drugs in the previous month were the exclusion criteria. Based on the history obtained from the parents, none of the controls had a history of delayed development.

The study was approved by Keçiören Training and Research Hospital Ethics Committee (number 24.12.2014/B.10.4.ISM.4.06.68.49).

All participants' rights were protected. The parents or legal guardian of each participant were informed about the study and then written consent was obtained from them before the procedures in accordance with the Declaration of Helsinki.

\section{Assessment Measures}

A sociodemographic data form was used to obtain sociodemographic characteristics including age, sex, history of autistic regression, pregnancy and birth history, family history, and medical history.

Childhood Autism Rating Scale (CARS): The childhood autism rating scale (CARS) comprises 15 items to define the severity of autism. Each item is rated on a scale from 1 to 4 with a half-degree score. A total score of 30 to 36.5 indicates mild-to-moderate autism, while 37 to 60 shows severe autism. The validity and reliability of the Turkish version of CARS were confirmed previously (11-13).

Autism Behavior Checklist (ABC): The autism behavior checklist (ABC) comprises 57 items to determine the ASD symptoms via five sub-scales: Sensory, Relating, Body and Object Use, Language, and Social Self-Help skills. The sum of these scores constitutes the total $\mathrm{ABC}$ score and this can be between 0 and 159 points with a cut-off point of 39 . The validity and reliability of the Turkish version of the $\mathrm{ABC}$ were confirmed previously $(14,15)$.

The ABC and the CARS were used only in the study group. The $\mathrm{ABC}$ was filled out by parents with guidance from a researcher. The CARS was applied by the same researcher. The CARS and the $\mathrm{ABC}$ were applied on the same day that the serum sample was taken. 


\section{Measurement of Serum S100B}

A blood sample was collected from all participants by venipuncture in a vacutainer tube without anticoagulant. Blood samples were taken at any time of the day. The samples were allowed to clot for about 30 minutes at room temperature and then were centrifuged. Following centrifugation, the serum part was separated and aliquoted in an Eppendorf tube and stored at $-80{ }^{\circ} \mathrm{C}$ until analysis. All serum samples were analyzed on the same day with the same laboratory batch and by the same analyst. A YHBiosearch Human S100B enzyme-linked immunosorbent assay (ELISA) kit was used with a sensitivity $5.03 \mathrm{ng} / \mathrm{L}$ to measure S100B levels according to the manufacturer's instructions. The lower detection limit is $10 \mathrm{ng} / \mathrm{L}$ and the upper is $4000 \mathrm{ng} / \mathrm{L}$ in this kit. The coefficients of variation were $<10 \%$ and $<12 \%$ for intra-assay and inter-assay variability, respectively. S100B levels were expressed as $\mathrm{pg} / \mathrm{ml}$.

\section{Statistical Analysis}

The statistical package for the social sciences (SPSS) version 22.0 (NY: IBM Corp., 2012) was used. Descriptive statistics were presented as mean and standard deviation, median, interquartile range (IQR), minimum-maximum, frequency distribution, and percentage. The normality of the distribution of numeric variables was tested with the Shapiro-Wilk test. The homogeneity of variances was tested using the Levene test. For variables with a normal distribution the independent samples t test was used for comparisons, whereas the Mann-Whitney U test was used for variables that did not conform to the normal distribution. Categorical variables were analyzed using Pearson's chi-square test, Fisher's exact test, and Yates' continuity correction. Spearman's correlation analysis was carried out to determine correlations and $\mathrm{p}$ values $<0.05$ were regarded as statistically significant.

\section{RESULTS}

A total of 52 male (25 with ASD, 27 controls) were included. Their sociodemographic characteristics are presented in Table 1 .

The birth/pregnancy histories of the groups were similar. Descriptive statistics of their prenatal, natal, and postnatal characteristics are presented in Table 2.

Mean serum S100B levels were $1008.61 \pm 171.34 \mathrm{pg} / \mathrm{ml}$ in the ASD group and $1060.14 \pm 182.83 \mathrm{pg} / \mathrm{ml}$ in the control group. There was no statistically significant difference between the two groups in terms of serum S100B levels $(\mathrm{p}=0.300)$.

Table 1. Sociodemographic characteristics of the ASD and control groups

\begin{tabular}{|c|c|c|c|}
\hline & $\operatorname{ASD}(n=25)$ & Control $(n=27)$ & $\mathbf{p}$ \\
\hline Age (months), mean \pm SD & $48.6 \pm 10.5$ & $44.6 \pm 15.3$ & $0.272^{\mathrm{a}}$ \\
\hline Fathers' age* (years), median (IQR) [min-max] & $30(9)[23-50]$ & $30(7.5)[18-43]$ & $0.317^{\mathrm{b}}$ \\
\hline Mothers' age* (years), median (IQR) [min-max] & 25 (10) [17-39] & $26(7)[18-43]$ & $0.514^{\mathrm{b}}$ \\
\hline Consanguineous marriage, $\mathrm{n}(\%)$ & $3(12.0)$ & $5(18.5)$ & $0.705^{\mathrm{c}}$ \\
\hline Psychiatric disorder history of family, n (\%) & $3(12.0)$ & $4(14.8)$ & $0.998^{\mathrm{c}}$ \\
\hline Sibling, n (\%) & $23(92.0)$ & $20(74.1)$ & $0.143^{\mathrm{c}}$ \\
\hline Psychiatric disorder history of sibling $(n=43)^{* *}, n(\%)$ & $1^{\#}(4.3)$ & $1^{\#}(5.0)$ & $0.999^{\mathrm{c}}$ \\
\hline \multicolumn{4}{|l|}{ Birth order, n (\%) } \\
\hline First & $6(24.0)$ & $13(48.2)$ & \\
\hline Second & $15(60.0)$ & $10(37.0)$ & $0.173^{\mathrm{d}}$ \\
\hline Third & $4(16.0)$ & $4(14.8)$ & \\
\hline
\end{tabular}

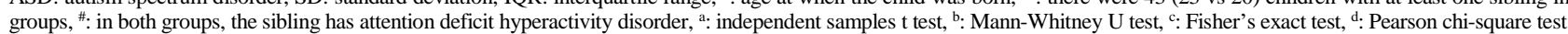

Table 2. Prenatal, natal, and postnatal characteristics of the ASD and control groups

\begin{tabular}{|c|c|c|c|}
\hline & $\operatorname{ASD}(n=25)$ & Control $(n=27)$ & $\mathbf{p}$ \\
\hline Prenatal disease history, n (\%) & $6(24.0)$ & $3(11.1)$ & $0.284^{\mathrm{a}}$ \\
\hline Prenatal drug exposure, n (\%) & $3(12.0)$ & $1(3.7)$ & $0.341^{\mathrm{a}}$ \\
\hline Prenatal cigarette smoking exposure, $\mathrm{n}(\%)$ & $1(4.0)$ & $0(0.0)$ & $0.481^{\mathrm{a}}$ \\
\hline Gestational age, $\mathrm{n}(\%)$ & & & \multirow[b]{2}{*}{$0.998^{\circ}$} \\
\hline $\begin{array}{l}\text { Term } \\
\text { Preterm }\end{array}$ & $\begin{aligned} 23 & (92.0) \\
2 & (8.0)\end{aligned}$ & $\begin{array}{c}24(88.9) \\
3(11.1)\end{array}$ & \\
\hline $\begin{array}{l}\text { Birth pattern, } \mathrm{n}(\%) \\
\text { Normal spontaneous vaginal delivery } \\
\text { Cesarean section }\end{array}$ & $\begin{array}{c}9(36.0) \\
16(64.0)\end{array}$ & $\begin{array}{c}8(29.6) \\
19(70.4)\end{array}$ & $0.847^{\mathrm{b}}$ \\
\hline Birth weight (gram), mean \pm SD & $3376.8 \pm 711.4$ & $3259.1 \pm 592.3$ & $0.519^{\mathrm{c}}$ \\
\hline Birth complication history, $\mathrm{n}(\%)$ & $2(8.0)$ & $4(14.8)$ & $0.670^{\mathrm{a}}$ \\
\hline Postnatal jaundice history, n (\%) & $4(16.0)$ & $3(11.1)$ & $0.698^{\mathrm{a}}$ \\
\hline Postnatal disease history, n (\%) & $3(12.0)$ & $2(7.4)$ & $0.662^{\mathrm{a}}$ \\
\hline
\end{tabular}

ASD: autism spectrum disorder, SD: standard deviation, a: Fisher's exact test, b: Yates' continuity correction, c: Independent samples t test 
The ABC-subscales and total scores and the CARS scores of the ASD group $(n=25)$ are shown in Table 3. Based on the CARS scores, $60 \%$ of the children $(n=15)$ with ASD had severe autism, whereas $40 \%(n=10)$ had mild-to-moderate autism.

Mean serum S100B levels were $1007.09 \pm 199.48 \mathrm{pg} / \mathrm{ml}$ in mild-to-moderate autism and $1009.62 \pm 157.31 \mathrm{pg} / \mathrm{ml}$ in severe autism according to CARS scores. There was no significant difference between the mild-to-moderate and severe autism groups in terms of serum S100B levels $(\mathrm{p}=0.935)$.

In the ASD group, no correlation was found between serum S100B levels and CARS or ABC-total or -subscale scores (Table 4).

Mean serum S100B levels were $1026.80 \pm 170.54 \mathrm{pg} / \mathrm{ml}$ in male who had autistic regression and $998.38 \pm 176.50$ $\mathrm{pg} / \mathrm{ml}$ in those who did not have autistic regression. There was no significant difference between serum S100B levels and autistic regression status in the ASD group $(\mathrm{p}=0.667)$.

\section{DISCUSSION}

In the present study, serum S100B levels were evaluated. The normal range values of S100B remain unclear. There are studies in the literature to determine the normal range of S100B in a non-diseased group, as well as studies to compare S100B levels between two groups including a study group with a disorder and a control group. Therefore, it can be concluded that our knowledge about S100B values is limited to the studies that have been conducted so far. Our results will be discussed in the light of these previous studies. To understand and interpret the results in the literature, it is useful to know that $1 \mathrm{ng} / \mathrm{L}$ equals $1 \mathrm{pg} / \mathrm{ml}$ and $1 \mu \mathrm{g} / \mathrm{L}$ equals $1000 \mathrm{pg} / \mathrm{ml}$.

In the meta-analysis study by Zheng et al. (16), it was stated that peripheral blood S100B levels might have potential as a useful biomarker for ASD. In our study there was no difference in serum S100B levels between the study and control groups. This result is consistent with the study conducted by Esnafoglu et al. (2) that reported no difference between their study group including children with ASD and a control group. However, in other studies higher S100B levels were reported in children with ASD compared to controls. In the study by Tomova et al. (5), higher plasma S100B levels were reported in children diagnosed with autism compared to non-autistic controls. Similar results have also been reported by Ayaydin et al. (8) and by Golubova et al. (9) with serum S100B levels in the ASD group being higher than those in the control group. It appears that there is inconsistency between the studies' results. Both to use S100B as a biomarker for ASD and to elucidate ASD pathogenesis, it should be considered why such results were obtained. In our discussion part we attempt to explain and interpret these issues. In the meta-analysis study by Zheng et al. (16), no difference was found between the ASD and control groups in terms of S100B levels in China and Turkey. The authors claimed this might have been related to genetic factors, environmental factors, lifestyle, and economic conditions.

As mentioned above, although the normal range of S100B is not fully clarified yet, in our study we found serum S100B levels in both the study and control groups much higher than those in most other studies conducted in serum
Table 3. CARS and ABC scores in the ASD group ( $n=25)$

\begin{tabular}{lcc}
\hline & Mean \pm SD & Median (min-max) \\
\hline CARS & $38.48 \pm 6.31$ & $39(30-50)$ \\
ABC-Total & $58.80 \pm 27.15$ & $54(18-132)$ \\
ABC-Sensory & $7.84 \pm 5.07$ & $7(0-25)$ \\
ABC-Relating & $17.36 \pm 7.29$ & $17(4-29)$ \\
ABC-Body and Object Use & $9.80 \pm 8.10$ & $8(0-34)$ \\
ABC-Language & $12.88 \pm 5.97$ & $11(4-28)$ \\
ABC-Social and Self-Help & $10.92 \pm 5.27$ & $11(3-19)$ \\
\hline
\end{tabular}

ASD: autism spectrum disorder, CARS: childhood autism rating scale, ABC: autism behavior checklist, SD: Standard deviation, min-max: minimum-maximum

Table 4. The correlation of CARS, ABC, and serum S100B levels in the ASD group $(n=25)$

\begin{tabular}{lcc}
\hline & \multicolumn{2}{c}{ S100B } \\
\cline { 2 - 3 } & rs & p \\
\hline CARS & -0.080 & 0.705 \\
ABC-Total & -0.100 & 0.635 \\
ABC-Sensory & -0.044 & 0.835 \\
ABC-Relating & -0.094 & 0.656 \\
ABC-Body and Object Use & 0.022 & 0.917 \\
ABC-Language & 0.019 & 0.930 \\
ABC-Social and Self-Help & -0.304 & 0.140 \\
\hline ASD:
\end{tabular}

ASD: autism spectrum disorder, CARS: childhood autism rating scale, ABC: autism behavior checklist, $\mathrm{r}_{\mathrm{s}}$ : Spearman's rho

to determine S100B levels $(2,7,8)$. Mean serum S100B levels in our study were $1008.61 \pm 171.34 \mathrm{pg} / \mathrm{ml}$ in the ASD group and $1060.14 \pm 182.83 \mathrm{pg} / \mathrm{ml}$ in the control group. In the study by Astrand et al. (17), the venous serum S100B protein reference value was $0.15 \mu \mathrm{g} / \mathrm{L}$ (equal to $150 \mathrm{pg} / \mathrm{ml}$ ) in neurologically healthy children aged 3-14 years. In the study by Castellani et al. (18) including children from 3 to 18 years with no recent history of head injury, serum S100B averaged $0.10 \mu \mathrm{g} / \mathrm{L}$ (equal to $100 \mathrm{pg} / \mathrm{ml}$ ) and the upper reference level was determined as $0.16 \mu \mathrm{g} / \mathrm{L}$ (equal to $160 \mathrm{pg} / \mathrm{ml}$ ). In the study by Bouvier et al. (19), it was aimed to determine serum S100B levels of healthy children under 3 years old. After some analyses, mean $\mathrm{S} 100 \mathrm{~B}$ of $0.11 \mu \mathrm{g} / \mathrm{L}$ (equal to $110 \mathrm{pg} / \mathrm{ml}$ ) was proposed. In the same study it was also reported that the standard deviation is 0.03 , range is $0.07-0.20$, and 95 th percentile is 0.18 . It is helpful to keep in mind that these three studies used an electrochemiluminescence immunoassay (17-19). Although high levels were found in the ASD group, the control group also had high levels in our study. When looking at the studies conducted in ASD groups, as stated in the meta-analysis by Zheng et al. (16), different results and ranges stand out. To give some examples of the serum S100B level in children with ASD, it was reported to be $3.33 \pm 4.19 \mathrm{pg} / \mathrm{ml}$ by Esnafoglu et al. (2), 207.97 \pm 52.6 $\mathrm{pg} / \mathrm{ml}$ by Al-Ayadhi and Mostafa (7), and 49.13 \pm 1.57 $\mathrm{pg} / \mathrm{ml}$ by Ayaydin et al. (8). Although Ayaydin et al. (8) found higher S100B protein levels in children with ASD compared to the healthy group, the mean value might be considered not so high compared to the studies to determine normal ranges $(17,18)$. The study conducted by 
Esnafoglu et al. (2) might be regarded in the same way so that even though no differences were found in terms of $\mathrm{S} 100 \mathrm{~B}$ values, the mean value of $3.33 \pm 4.19 \mathrm{pg} / \mathrm{ml}$ seems much lower compared to other studies aimed to determine S100B and ASD relations. In line with all these studies conducted to determine the S100B value and its associations, just comparing the results of two groups appears insufficient to determine the $\mathrm{S} 100 \mathrm{~B}$ range values or the pathogenesis of disorders. Moreover, just finding higher levels in patient groups compared to control groups in any disorder seems insufficient to consider S100B a reliable biomarker.

Putting aside some issues mentioned before, it is still possible to say that our S100B values are much higher than those of most other studies. In the rest of our discussion section, we attempt to establish why the results obtained were so high. In the literature, S100B values have been reported to decrease with age $(17,19)$. Our study was conducted in male younger than 6 years old. To exemplify some other studies' age ranges, it was 5-12 years in the study by Al-Ayadhi and Mostafa (7) and it was 3-12 years in the study by Ayaydin et al. (8). The higher values of S100B in our study may have been related to the fact that the ages of the patients were lower than in those studies. Bouvier et al. (19) explained the high concentrations of S100B under 3 years of age by the possible permeability of the blood brain barrier and cerebral circulation, increased protein turnover in neuronal cells, and low renal excretion of S100B. In the same study another explanation for the higher concentrations of S100B found in neonates and children than in adults was that it could reflect the dynamic central neurodevelopmental processes in which S100B plays a role. Our study was conducted in only male participants, whereas the others included both sexes $(7,8)$. The association of S100B with sex is not clearly depicted. Astrand et al. (17) found a difference between the sexes only in serum capillary S100B levels at 1 and 2 years of age in neurologically healthy children, whereas they found no difference in serum S100B levels in the 3-14 age group or in venous samples between the two sexes aged 3-14 years. However, another study revealed that the correlation of S100B levels between capillary and venous samples was low (20). Castellani et al. (18) and Bouvier et al. (19) found no significant difference between the sexes in children in terms of S100B values. As a meta-analysis has revealed, high levels of heterogeneity were detected in studies conducted for investigation of the association of S100B with ASD (16). While interpreting all the results, this should be taken into consideration. In the meta-analysis study by Zheng et al. (16), it was found that individuals with ASD who had higher peripheral blood S100B levels were detected in cross-sectional studies but not in case-control studies. This situation indicated that the results might have been affected by the study design.

Besides these issues, there might be some other factors potentially capable of affecting S100B levels. S100B can be measured by several methods, such as immunoradiometric assay, immunoluminometric assay, mass spectroscopy, western blot, enzyme linked immunosorbent assay, electrochemiluminescence, and quantitative polymerase chain reaction (21). Müller et al. (22) reported that the choice of analytical method might influence the result of $\mathrm{S} 100 \mathrm{~B}$ serum analysis. In the same study it was revealed that different methods for the determination of S100B concentrations have not been found interchangeable. It has been suggested that when planning and interpreting the results of clinical studies, all these factors must be taken into consideration (22). As a result, it may be surmised that the different measurement methods between ours and other studies might have caused differences in S100B levels. In the meta-analysis study by Zheng et al. (16), a wide range of mean S100B values reported across studies was found. According to the authors these results might have been related to the studies included, which used different measurement units and different analytical technologies.

Skogstrand et al. (23) have reported that some biomarkers like BDNF, S100B, VEGF-A, and IL-18 may be affected by being frozen. Moreover, increased fragility to a freeze-thaw cycle has been reported especially in samples stored for more than 15 years. Müller et al. (22) claimed that the duration of sample storage may influence the result of S100B serum analysis. They found serum S100B concentrations increased in most samples stored 6 years before, while $13 \%$ of the reanalyzed samples showed decreased concentrations. However, Ikeda and Umemura (24) showed that serum S100B values measured from the same frozen sample after 2 months and after 9 months were almost the same. In our study the analysis of serum S100B values was performed within one year at the latest of the samples being frozen. Hence, the time that passed between sample collection and sample analysis is assumed not to have affected the S100B values in our study. Raabe et al. (25) noted that S100B can be measured in arterial or venous serum, is not affected by hemolysis, and remains stable over hours without the need for immediate centrifugation and freezing of the sample; moreover, no special technique is required for sampling or analysis.

In our study, the samples were collected at any time of the day. Ikeda and Umemura (24) showed that serum S100B protein levels were not affected by the circadian rhythm. Likewise, Morera-fumero et al. (6) found no circadian rhythm in S100B levels. In the same study different S100B values were seen due to the season, whether it is summer or winter, with higher values in summer than in winter. Although similar results in terms of higher S100B values in summer were shown by Henriksson AE. (26), the similarity was not statistically significant. The summer/winter difference has been explained by the seasonal temperature changes or the influence of physical activities based on the previous studies. In our study serum samples were collected between January and June. In Turkey, January is a winter month whereas June is a summer month. Thus it might be presumed that seasonal changes were involved that might have affected S100B values when conducting our study. In another study, a day/night variation in S100B levels has been shown with serum S100B levels at 12:00 (midday) being higher than those at 00:00 (midnight) in schizophrenia patients at the time of admission to the inpatient clinic. This day/night difference was not seen in the healthy control group or at discharge time in the schizophrenia patients either (27). It has been documented that both ADHD and healthy control groups had higher serum S100B concentrations in the mornings than in the evenings (28). Considering all, it may 
be concluded that whether this is related to a psychiatric disorder pathophysiology or S100B circadian rhythm remains unclear. In the light of these studies it is assumed that the technical issues mentioned above did not affect our $\mathrm{S} 100 \mathrm{~B}$ values, although it is unclear whether some of them might have been affected. As mentioned before, the usefulness of some features for interpreting S100B results is still unclear. Thus, for using S100B values in the health system reliably, it is suggested that the reasons for previous studies' different results need to be researched further. In future studies, it must be revealed more clearly whether biochemical materials and methods, circadian rhythm, seasonal factor, sex factor, age factor, etc. affect S100B results. Therefore, future research might be designed considering and minimizing all these factors for better and clearer results.

Regarding S100B levels in terms of severity, there are some studies investigating the S100B and ASD relationship. Guloksuz et al. (10) found higher plasma $\mathrm{S} 100 \mathrm{~B}$ values in severe ASD than in mild-to-moderate ASD based on CARS scores but also showed that S100B concentrations were no longer significantly different between children with severe ASD and those with less severe ASD after controlling for age, sex, and BMI. In the study conducted by Golubova et al. (9), serum S100B levels were found higher in children with severe ASD. On the other hand, although Al-Ayadhi and Mostafa (7) revealed a positive correlation between CARS score and serum S100B levels in ASD patients it was not statistically significant. Shaker et al. (29) revealed that autism patients had higher serum S100B levels compared to healthy controls but no significant correlation between S100B levels and severity of autism was found. It is important to keep in mind that in their study a different assessment tool (Gilliam Autism Rating Scale) was used to determine autism severity. In our study there was no statistically significant relationship between serum S100B levels and autism severity based on CARS scores. Moreover, no statistically significant relationship was found between serum S100B levels and ABC total and subscores either. To elucidate the relation between ASD symptom severity and S100B values, more studies are needed.

A subset of children experience a period of apparently normal development for the first one to two years of life, followed by an abrupt or gradual loss of previously acquired skills, a phenomenon termed regression. The phenomenon of developmental regression, or the loss of a previously established skill, has been discussed in the autism literature (30). In our study, 36\% ( $n=9)$ of the ASD subjects had autistic regression. According to the results of our study no statistically significant difference was found between ABC-subscale scores, ABC-total scores, CARS scores, and serum S100B levels in terms of autistic regression status. The absence of a statistically significant difference between the autistic regression status and serum S100B levels in our study group may indicate the lack of more CNS injury in individuals with autistic regression. However, the absence of a statistically significant difference in serum S100B levels between the study group and the control group may be considered to refute this theory.

There were some limitations of the present study. It can be presumed that the limited sample size, not comparing the age ranges and sex differences, and the absence of BMI evaluation were limitations of this study. Although all confirmed cases of neurological diseases were excluded, the absence of neurological and general pediatric examinations might have caused some situations in which the effects were involved. The absence of detailed questioning about the situations that might affect serum S100B protein levels prior to the study may be considered a limitation as well.

\section{CONCLUSION}

No statistically significant difference was found in serum S100B levels in ASD and no relation between S100B and $\mathrm{ABC}$ or CARS scores. Due to the fact that no significant difference was found between CARS scores and S100B values, it was concluded that there was no relationship between autism severity and serum S100B values. No statistically significant difference was found between serum S100B levels with regard to autistic regression status either. Performing similar studies with larger samples in the future is thought to be helpful for elucidating the etiopathogenesis of ASD. Just comparing the S100B results of two groups seems insufficient for considering S100B protein a reliable biomarker. More studies considering some factors (biochemical materials and methods, circadian rhythm, seasonal factor, sex factor, age factor, etc.) with larger samples should be performed. Moreover, to understand the effect of biochemical methodology on the results, further studies are suggested on this topic.

Ethics Committee Approval: The study was approved by the Ethics Committee of Keçiören Training and Research Hospital (24.12.2014, B.10.4.ISM.4.06.68.49).

Conflict of Interest: None declared by the authors.

Financial Disclosure: None declared by the authors.

Acknowledgements: None declared by the authors.

Author Contributions: Idea/Concept: ANE, ID, ŞB; Design: ANE, ID, ŞB; Data Collection/Processing: ANE, ID, ŞB, ÖDT; Analysis/Interpretation: ANE, İD, ŞB, ÖDT; Literature Review: ANE, ID, ŞB; Drafting/Writing: ANE, İD, ŞB; Critical Review: ANE, ID, ŞB, ÖDT.

\section{REFERENCES}

1. American Psychiatric Association. Diagnostic and statistical manual of mental disorders. $5^{\text {th }}$ ed. Washington DC: American Psychiatric Association; 2013.

2. Esnafoglu E, Ayyıldız SN, Cirrık S, Erturk EY, Erdil A, Daglı A, et al. Evaluation of serum Neuron-specific enolase, S100B, myelin basic protein and glial fibrilliary acidic protein as brain specific proteins in children with autism spectrum disorder. Int $\mathrm{J}$ Dev Neurosci. 2017;61:86-91.

3. Kleindienst A, Hesse F, Bullock MR, Buchfelder M. The neurotrophic protein S100B: value as a marker of brain damage and possible therapeutic implications. Prog Brain Res. 2007;161:317-25. 
4. Michetti F, D'Ambrosi N, Toesca A, Puglisi MA, Serrano A, Marchese E, et al. The S100B story: from biomarker to active factor in neural injury. $\mathrm{J}$ Neurochem. 2019;148(2):168-87.

5. Tomova A, Keményová P, Filčíková D, Szapuová Ž, Kováč A, Babinská K, et al. Plasma levels of glial cell marker S100B in children with autism. Physiol Res. 2019;68(Suppl 3):S315-23.

6. Morera-Fumero AL, Abreu-Gonzalez P, HenryBenitez M, Yelmo-Cruz S, Diaz-Mesa E. Summer/winter changes in serum S100B protein concentration as a source of research variance. J Psychiatr Res. 2013;47(6):791-5.

7. Al-Ayadhi LY, Mostafa GA. A lack of association between elevated serum levels of S100B protein and autoimmunity in autistic children. J Neuroinflammation. 2012;9:54.

8. Ayaydın H, Kirmit A, Çelik H, Akaltun İ, Koyuncu I, Bilgen Ulgar Ş. High serum levels of serum 100 beta protein, neuron-specific enolase, tau, active caspase-3, M30 and M65 in children with autism spectrum disorders. Clin Psychopharmacol Neurosci. 2020;18(2):270-8.

9. Golubova TF, Tsukurova L, Korsunskaya LL, Osipyan RR, Vlasenko SV, Savchuk EA. [S100B protein in the blood of children with autism spectrum disorders]. Zh Nevrol Psikhiatr Im S S Korsakova. 2019;119(12):7683. Russian

10. Guloksuz SA, Abali O, Aktas Cetin E, Bilgic Gazioglu S, Deniz G, Yildirim A, et al. Elevated plasma concentrations of S100 calcium-binding protein B and tumor necrosis factor alpha in children with autism spectrum disorders. Braz J Psychiatry. 2017;39(3):195200.

11. Schopler E, Reichler RJ, DeVellis RF, Daly K. Toward objective classification of childhood autism: Childhood Autism Rating Scale (CARS). J Autism Dev Disord. 1980;10:91-103.

12. İncekaş Gassaloğlu S, Baykara B, Avcil S, Demiral Y. [Validity and reliability analysis of Turkish version of childhood autism rating scale]. Turk Psikiyatri Derg. 2016;27(4):266-74. Turkish.

13. Sucuoğlu B, Öktem F, Akkök F, Gökler B. A study about childhood autism scales. Psikiyatri Psikol Psikofarmakol Derg. 1996;4(2):116-21. Turkish.

14. Krug DA, Arick JR, Almond PA. ASIEP-2: autism screening instrument for educational planning. $2^{\text {nd }}$ ed. Austin, Texas: Pro-ed Inc.; 1993.

15. Yılmaz Irmak T, Tekinsav Sütçü S, Aydın A, Sorias O. An investigation of validity and reliability of autism behavior checklist (ABC). Turk J Child Adolesc Ment Health 2007;14(1):13-23. Turkish.

16. Zheng Z, Zheng P, Zou X. Peripheral blood S100B levels in autism spectrum disorder: A systematic review and meta-analysis. J Autism Dev Disord. 2021;51(8):2569-77.

17. Astrand R, Romner B, Lanke J, Undén J. Reference values for venous and capillary S100B in children. Clin Chim Acta. 2011;412(23-24):2190-3.
18. Castellani C, Stojakovic T, Cichocki M, Scharnagl H, Erwa W, Gutmann A, et al. Reference ranges for neuroprotein S-100B: from infants to adolescents. Clin Chem Lab Med. 2008;46(9):1296-9.

19. Bouvier D, Castellani C, Fournier M, Dauphin JB, Ughetto S, Breton M, et al. Reference ranges for serum S100B protein during the first three years of life. Clin Biochem. 2011;44(10-11):927-9.

20. Vedin T, Karlsson M, Edelhamre M, Bergenheim M, Larsson PA. Prospective comparison of capillary and venous brain biomarker S100B: capillary samples have large inter-sample variation and poor correlation with venous samples. Int J Emerg Med. 2019;12(1):26.

21. Sedaghat F, Notopoulos A. S100 protein family and its application in clinical practice. Hippokratia. 2008;12(4):198-204.

22. Müller K, Elverland A, Romner B, Waterloo K, Langbakk B, Undén J, et al. Analysis of protein S-100B in serum: a methodological study. Clin Chem Lab Med. 2006;44(9):1111-4.

23. Skogstrand K, Hagen CM, Borbye-Lorenzen N, Christiansen M, Bybjerg-Grauholm J, Bækvad-Hansen $\mathrm{M}$, et al. Reduced neonatal brain-derived neurotrophic factor is associated with autism spectrum disorders. Transl Psychiatry. 2019;9(1):252.

24. Ikeda Y, Umemura K. [Analysis of reference values of serum S100B concentrations of Japanese adults]. Rinsho Byori. 2005 May;53(5):395-9. Japanese.

25. Raabe A, Grolms C, Keller M, Döhnert J, Sorge O, Seifert V. Correlation of computed tomography findings and serum brain damage markers following severe head injury. Acta Neurochir (Wien). 1998;140(8):787-91; discussion 791-2.

26. Henriksson AE. S100B and the influence of seasonal variation. Scand J Clin Lab Invest. 2016;76(4):338-40.

27. Morera-Fumero AL, Díaz-Mesa E, Abreu-Gonzalez P, Fernandez-Lopez L, Cejas-Mendez MDR. Day/night changes in serum S100B protein concentrations in acute paranoid schizophrenia. Prog Neuropsychopharmacol Biol Psychiatry. 2017;75:20712.

28. Fernández-López L， Molina-Carballo A, CuberoMillán I, Checa-Ros A, Machado-Casas I, BlancaJover E, et al. Indole tryptophan metabolism and cytokine S100B in children with attentiondeficit/hyperactivity disorder: daily fluctuations, responses to methylphenidate, and interrelationship with depressive symptomatology. J Child Adolesc Psychopharmacol. 2020;30(3):177-88.

29. Shaker NM, Taha GRA, Kholeif H, Sayed NM, ElSheikh MM, Abulmagd ML. Serum levels of S100B, interleukin-6 and anti-transglutaminase Ii $\operatorname{IgA}$ as immune markers in a sample of Egyptian children with autistic spectrum disorders. Autism Open Access. 2016;6(5):191.

30. Barger BD, Campbell JM, McDonough JD. Prevalence and onset of regression within autism spectrum disorders: a meta-analytic review. J Autism Dev Disord. 2013;43(4):817-28. 